\title{
Entrepreneurial Skill Development in Woodwork Trade: A Panacea to the Challenges of Youth Unemployment
}

\author{
Omeje Hyginus Osita \\ Department of Woodwork Technology Education \\ School of Industrial Technical Education, Federal College Of Education (Technical), \\ Umunze, Anambra State, Nigeria.
}

\section{Doi:10.5901/mjss.2013.v4n8p99}

\begin{abstract}
The changing economies in many developing countries have forced governments and educators to place a high priority on entrepreneurial skill training and development. The major thrusts of technical and vocational education (TVE) in Nigeria amongst other things are to address issues of self reliance, job creation, youth unemployment, poverty and international competitiveness in skills development towards current and projected opportunities and challenges. Such issues are crucial particularly to Nigeria and to Africa's dignity and survival in general in the fast-changing global environment. This paper highlights on the concepts, issues and need for entrepreneurial skill acquisition in woodwork trades in addressing the problems of youth unemployment in Nigeria. The paper also identified some challenges to effective entrepreneurial skill development in TVE. Some recommendations were made, based on the identified challenges.
\end{abstract}

\section{Introduction}

In Nigeria today, youth employment challenges is causing the government a great deal of concern. According to Idoko (2010), it is estimated that about 4.5 million youths, mostly educated, are entering the labour market annually. He pointed out that in order to prevent the unusually high level of youth unemployment and underdevelopment rates from getting higher, the government should take urgent ameliorative action. Also, Obi (2010) asserted that mass unemployment which has been evident in the last two decades has reached alarming proportions and involved all categories of labour-skilled and unskilled persons, university graduates and specialist individuals. There is therefore the need to massively equip the youth with useful trade and entrepreneurship skills necessary to elevate them from their present condition of poverty and joblessness, to a vibrant and entrepreneurial youth, ready to contribute to the development of the nation.

Idoko (2010) stated that since up to 40 percent of the employment created in Nigeria is through self- or "own account" employment, it is vital that trainees who graduate from Technical and Vocational institutions are prepared to create their own employment. Therefore the trainers in technical and vocational education trades must not only provide the trainees with the essential technical and vocational skills needed for employment but also with the entrepreneurial skill and ability to create their own businesses.

\section{Concept of Entrepreneurship}

An entrepreneur is a risk-taking businessperson, somebody who initiates or finances new commercial enterprises. Entrepreneurship education on the other hand is the means of instilling the qualities of entrepreneurship in people with the continued general activities of managers or what can be the purposeful activity of an individual, undertaken to initiate, maintain or organize, a profit oriented business unit for the 
production or distribution of economic goods and services. According to lloka (2010), entrepreneurship functions as that of making strategically important or innovative decisions.

Entrepreneurial competency refers to the sum of the entrepreneur's requisite attributes for successful and sustainable entrepreneurship (Kiggundy, 2002). According to Kiggundy, these attributes include attitudes, values, beliefs, knowledge, skills, abilities, personality, wisdom, expertise (social, technical, and managerial), mindset, and behavioral tendencies. Cunningham and Lischeron (1991) identified six schools of thought on entrepreneurship that explain what constitutes an entrepreneur. Of the six schools, three assert that entrepreneurial traits are innate.

\section{The Need for Entrepreneurial Skill Development in Woodwork}

Despite the inclusion of entrepreneurship education in the curricular of tertiary institutions in Nigeria, the achievement of the goals and objectives of technical and vocational education in terms of seeking to relate education to employment, job creation and self-reliance has remained illusive. According to Obi (2010) the potential rudimental competences of entrepreneurship are presently lacking in vocational training and education. The entrepreneurial spirit/skills and attitude development in such trades like Woodwork are lacking in the entrepreneurship education as presently mounted in tertiary institutions.

Woodworking is the act, art or trade of working with wood. It is the process of building, making or carving something using wood. Woodwork is a profitable business among a few woodworkers in Nigeria, who are still in the trade despite societal poor image that is ascribed to the trade. This societal poor image on woodwork as a trade, no doubt, could be responsible for low self esteem usually suffered by the practitioners of the trade, and which may have resulted in the societal view of the trade as unattractive. There are many reasons for which people discontinue with their chosen career or area of studies. Amongst these are: lack of financial means, parental unemployment; lack of communication at home; low self esteem; and lack of future perspective. The best way to reverse this trend is to bring out the entrepreneurial side of the person.

Woodwork is one of the major trade components of the curriculum of Technical and vocational Education. To a layman, Woodwork is derogatorily referred to as cut-and-join-technology, but Woodwork is much more than that. Like every other practical oriented disciplines, Woodwork require skills and business opportunities abound in the trades. It emphasizes learning by doing through cognitive and psychomotor skill.

Skill is the ability to do something well, usually gained through training or experience. Okorie (2000) defined skill as ease, rapidity, precision usually of muscular action. He further referred to skill as expertness, practiced ability, dexterity, and tact. To possess a skill is to demonstrate the habit of acting, thinking and behaving in a specific activity in such a way that the process becomes natural to the individual through repetition or practice. The major areas of Woodwork where entrepreneurial skill development is required include: furniture making; Carpentry and Joinery; upholstery; Machine Woodworking and Ornamental Woodwork (Woodcarving). Developing entrepreneurial skill in Woodwork is a sure way of curbing youth unemployment and reducing poverty.

According to Obi (2010) the ugly picture painted by mass unemployment in Nigeria demands deliberate and goal oriented approach to entrepreneurship education as different from the one presently established in tertiary institutions which is lope-sided, lacks practical content, and therefore impotent. It is lope-sided because according to him it is only taught in the classroom which is devoid of real world of work experiences. He therefore suggested a model of entrepreneurial skill development among Nigerian youths in tertiary institution whereby the various departments should run consultancy outfits or service-oriented workshops, where students in their departments will acquire, develop and build the desirable job skills before graduation.

Ogalanya in Anyaeneh (2010) classified the entrepreneurial skills required for self-employment into three broad areas namely; sound professional intellectual skills, job specific/technical skills and psycho-social skills each of which require training and can be broken down as follows:

Sound Professional/ Intellectual Skills- the skill development in this instance will focus on: managerial/ 
administrative skills-managing people and materials; planning/Conceptual skill-articulating ideas in a logical fashion; human relations skill-interpersonal relationship, management-labour relations; supervisory I Coordination skills-persuasiveness and communication (language) skills-power of accurate information dissemination.

Job Specific/Technical Skills-Skill development in this case will focus on: competitive and enterprising skills; creativity/innovative/imaginative skills; investigative/ problem solving skills; skill in the operation of gadgets and personal use competence.

Psycho-social skills-Serious attempt should be made to develop: high Motivation/strong will power/determination to succeed; honesty/Hard work/dedication to duty; self-discipline/selfconfidence/acceptance of challenges; respect for the dignity of labour- study of the profits of successful entrepreneurs in the locality and reward system-short term or long term, which will require patience and perseverance.

\section{Steps in developing Entrepreneurial Skill in Woodwork}

To educate young entrepreneurs in Woodwork in a successful manner it will be important to carry out the following activities:

- Carefully analyze the needs of the market to which you are directing the services of your enterprise, that is, the needs of young people in your area

- Look into the possibility of forming teams, especially one that would lead the project and its auxiliary or operative teams, some that coordinate and supervise, others that implement. To do this, it is necessary to determine beforehand a clear purpose for each team and distribute functions and roles accordingly.

- Conduct a detailed survey at the community level to establish what qualities they would like their children to develop at school. Gaining an impression of what success means to the community may help improve the relevancy of your education program me.

- Gather the greatest possible amount of information about what an entrepreneur Means to different community members. Focus groups, extended interviews and questionnaires can be a useful way of finding this out.

- It is important that local educational authorities are very familiar with the student/trainee entrepreneur project that is being carried out. Excellent communication with these authorities will help ensure that progress is not slowed down at a later date. It may be worthwhile presenting them with the action plan, and to give them an opportunity to offer input.

- Make a calendar of activities for tasks over the coming 12 months.

\section{Model Skill-Cluster: Mode of Instruction, Graduation Requirement and Distribution of Minimum Credit Require for Graduation}

\subsection{Mode of Instruction}

The mode of instruction for all the entrepreneurial skill area in Woodwork would be by tutorial, laboratory work/ practical as deemed appropriate for each skill area.

\subsection{Graduation Requirements}

Tutorials $=4$ weeks of 5 days per week $=20$ days.

Practical $=20$ weeks of 5 days per week $=100$ days. This should run Mondays through Fridays for all the skill areas. 


\subsection{Distribution of Minimum Credit Required for Graduation}

Based on a maximum credit load of 120 days for graduation, the tutorial should account for 4 weeks while practical should account for 20 weeks as follows:

Table 1.

\begin{tabular}{|c|l|c|c|c|}
\hline S/No & \multicolumn{1}{|c|}{ Skill Area } & Tutorial & Practicals & Total \\
\hline 1. & General Machine Woodworking & 20 days & 100 days & 120 days \\
\hline 2. & Carpentry \& Joinery & 20 days & 100 days & 120 days \\
\hline 3. & Interior Woodworking & 20 days & 100 days & 120 days \\
\hline 4. & & 20 days & 100 days & 120 days \\
\hline
\end{tabular}

\subsubsection{Sample Course Combination/Course Outline for each Entrepreneurial skill area Carpentry / Joinery \& Interior decoration}

Table 2.

\begin{tabular}{|c|l|c|c|c|}
\hline \multirow{2}{*}{ S/No Skill status } & \multicolumn{2}{|c|}{ Contact } & Credit Hours \\
\cline { 3 - 5 } & & Tutorial & Practical & \\
\hline 1. & Intro to Basic woodworking facilities and techniques used & 1 & 2 & 4 weeks \\
\hline 2. & Safety Precautions in wood workshop & 1 & - & 2 weeks \\
\hline 3. & Basic practical with classes of joints & - & 3 & 4 weeks \\
\hline 4. & Construction of items using joints & - & 3 & 2 weeks \\
\hline 5. & Project costing, estimating/ contract management & 1 & - & 4 weeks \\
\hline & Exam/ certification & & & 4 weeks \\
\hline
\end{tabular}

\subsubsection{General Machine Woodworking}

Table 3.

\begin{tabular}{|c|l|c|c|c|}
\hline \multirow{2}{*}{ S/No } & \multicolumn{1}{|c|}{ Skill status } & \multicolumn{2}{|c|}{ Contact } & Credit Hours \\
\cline { 3 - 5 } & & Tutorial & Practical & \\
\hline 1. & Safety Precautions in & 1 & 0 & 2 weeks \\
\hline 2. & Intro to Basic machine parts and functions & 1 & 0 & 2 weeks \\
\hline 3. & Fixed Machinery & 0 & 3 & 4 weeks \\
\hline 4. & Portable powered tools & 0 & 3 & 4 weeks \\
\hline 5. & Do it yourself attachments & 0 & 3 & 4 weeks \\
\hline & Exam/ certification & & & 4 weeks \\
\hline
\end{tabular}

\subsubsection{Furniture Making/ Upholstery}

Table 4.

\begin{tabular}{|c|l|c|c|c|}
\hline \multirow{2}{*}{ S/No Skill status } & \multicolumn{2}{|c|}{ Contact } & Credit Hours \\
\cline { 3 - 5 } & & Tutorial & Practical & \\
\hline 1. & Shaping and Wedging & - & 2 & 3 weeks \\
\hline 2. & Fitting table tops & - & - & 3 weeks \\
\hline 3. & Basic practical simple upholstery & - & 3 & 4 weeks \\
\hline 4. & Woven tops for chairs \& stools & 1 & - & 3 weeks \\
\hline 5. & Fitting and hinging doors, catches, locks and handles and others. & 1 & & 3 weeks \\
\hline & Exam/ certification & & & 4 weeks \\
\hline
\end{tabular}


Note: Each skill area as can be seen in the tables should be followed with an end of training examination based purely on practical skill acquisition. Assessment should also be based on the technique of observation.

\subsection{Characteristics of an 'entrepreneurial woodworker'}

An entrepreneurial woodworker is:

- Self-assured

- Tenacious

- Responsible

- Takes initiative

- Perseveres in face of adversity

- Acts with passion

- Achieves his/her goals

\subsection{How to Become a Successful Entrepreneur}

- Invite challenges

- Seek new skills

- Approach life and work with a positive attitude

- Recognize the need to transmit the entrepreneurial culture in all areas of education.

\section{You Must Do two Things to Become an Entrepreneurial Woodworker:}

- Overcome your own negative tendencies

- Engage in the outside world

\subsection{Overcoming your own negative tendencies:}

Fear of failure: is a normal feeling. It shouldn't become an obstacle to taking risks.

Losing inspires winners but ruins losers.

- Insecurity: It takes great courage not to let pessimistic and alarmist comments generate doubts and fears.

- Laziness: Action always triumphs over inaction!

- Arrogance: Acts as a shield for covering up our ignorance. An entrepreneur needs to be flexible and know their limitations so they can work to improve themselves.

\subsection{Engaging in the outside world:}

- Looking for inspiration from real examples of entrepreneurship in your local area.

- Create contact with someone who is already a successful entrepreneur.

- Invest in your own training and self improvement.

- Learn from the stories of the other entrepreneurial teachers.

- Think big and don't be afraid to dream, the world of ideas and reality come together in the entrepreneur.

- Actively seek out opportunities, check their viability and draw up a workable road map. 


\subsection{Activities involved in Training for Entrepreneurship in Woodwork:}

The following activities will be incorporated into the teaching of entrepreneurial skill in Woodworks;

i. Market survey: For homework students do market research tasks. For example students visit at least three different Woodworker's shop and at each shop find out how much they sell 3 different furniture items. During the following class students bring their data together and create statistics showing how prices for these items differs between neighborhoods and villages and how the price compares per item types.

ii. Trade enterprise statistics: For example, students calculate percentage profitability between different workshop enterprises, by using income and expenditure ratios.

iii. Training/Educational achievement statistics: Trainees analyze their own results between different years/semesters, seeing how their performance is improving or declining in percentage terms.

\subsection{Challenges to Effective Entrepreneurial Skill Development in TVE}

There are myriads of challenges facing the effective entrepreneurial skill development in technical and vocational education. The very few which this paper will just highlight on include:

Lack of funds- Inadequate funding had remained the most devastating problem of skill development in TVE. If TVE should meet-up with entrepreneurial skill development challenges, adequate funding should be a pre-requisite. The funding should not be left for federal government alone. Both State, local government, private organizations and NGOs should be mandated to help in funding entrepreneurial skill development programmes.

Inadequate supply of consumable- Institutions with the help of government should see to the provision of consumable for skill development.

Lack of interest on the part of the students- Skills can only be developed effectively when students have the interest and desire to learn. Because of the low image accorded to Woodwork, students tend to avoid practical skill training, thereby showing little interest in skill development.

No provision of in-service training for teachers- Most TVE teachers lack the competences and skill needed for the teaching of entrepreneurial skill development. There is therefore the need for in-service training through seminars and workshops for effective teaching of entrepreneurial skill development to the students.

\section{Conclusion}

The philosophy of technical and vocational education has always been on the acquisition of saleable skills for the youths which will make them to become asset to industries and useful to the society. This becomes more evident when the recipients are exposed early enough to entrepreneurial skill development. Development of basic entrepreneurial skill in Woodwork is a sure way of guaranteeing students self-reliance in the society. However this can only be achieved when a more aggressive but potent type of entrepreneurial skill development organized in real work situation is adopted, rather than its inclusion in the curriculum without adequate practical content. It is hoped that if entrepreneurial skill development is made core subject component of all the trades in TVE at all levels of education; the challenges posed by youth unemployment in Nigeria will be addressed.

\section{Recommendations}

Based on the identified challenges to effective entrepreneurial skill development in technical and vocational education, the paper recommends as follows: 
- The federal government of Nigeria should establish skill development centers for all vocational and technical institution from technical colleges to university level, based on core trade areas. This will instill in the recipients the entrepreneurial skills and competences needed to establish their own business on graduation.

- There should be capacity building workshop for technical and vocational teachers at all levels of education so as to embrace and update their skill in the teaching and learning issues involved in entrepreneurship skill development for their students.

- Students should be allowed to scout for jobs and also allowed to partake in the financial benefits derivable from the departmental consultancy services; this will go a long way in enhancing their future desire to own their own business.

- Institutions/departments should reach-out for private bodies and NGOs for partnership to run consultancy outfits for students' entrepreneurial skill development.

\section{References}

Ames, M. D. and Mahto, R.V (2007) Use of Volunteers in SBI to Increase Community Development and Outreach, Involve more students, and Improve Consulting: How can the Experience be successfully managed? Conference Proceedings on Entrepreneurship. Visited online at 20/10/12 at sbiames@fullerton.edu

Dixon, R. (2001) The Critical Entrepreneurial Competencies Required by Instructors from Institution-Based Enterprises: A Jamaican Study Visited online25/10/11 at http://www.jamaica.gleaner.com/gleaner/19990416/business/b3.html.

Cunningham, B., Lischeron, J. (1991). Defining Entrepreneurship. Journal of Small Business Management, 29(1), 45-58 [electronic version]

Encarta (2009), Microsoft Corporation.

Idoko, C (2010) Tackling Youth Unemployment Through vocational Skills Acquisition. Visited online 19/01/11 at http://www.skills-acquisition.htm

Jamaica Gleaner. (2001) Graduates urged to help transform economy. Retrieved April 22, 2003, from http://www.jamaica.gleaner.com/gleaner/20011029/busine ss/business1.html

Kiggundy, M. (2002). Entrepreneurs and entrepreneurship in Africa: What is known and what needs to be done. Journal of Developmental Entrepreneurship, 7(3), 239 - 258.

Maphosa, N and Phuthi, N (2010) Transforming higher Education for Effective Technical and Vocational Skills Delivery in Zimbabwe. Visited online at http://www.bc.edu/bc_org/avp/soe/cihe/inhea/profiles/Zimbabwe.htm

McGrath, S. 2005. Key issues and challenges for transformation. S. Akoojee, A. Gewer, S McGrath (eds.), Vocational Education and Training in Southern Africa. Free download www.hsrcpress.ac.za (Accessed 15 January 2007.)

Obi,W.J.D. (2010) Practical Based Skill Oriented Entrepreneurship Training in Secondary and Tertiary Institutions for Realization of Millennium development Goals. Journal of Technical Education Research and Development (JOTERD). Research and Conference Unit. F.C.E. (T), Umunze.

Okorie, J.U. (2000) Developing Nigeria's Workforce. Calabar. Macnky Environs Publishers.

Olaitan S.O.(1996) Vocational and Technical Education in Nigeria (Issues and Analysis). Onitsha. Noble Graphics Press.

School In A Box Guide Series (2008) Teach A Man To Fish and the Foundation Paraguaya. Manual 6 - How to Educate Successful Rural Entrepreneurs www.teachamantofish.org.uk

Ugwuogo, C. C. (2009) Skill Development in Business Education for the Millennium Development Goals (MDGs). Paper presented at the gth $^{\text {th }}$ ational Conference of the Federal College of Education (Technical), Umunze. Sept. $22^{\text {nd }}-25^{\text {th }}$. 
